\title{
WILDLIFE SPECIES DIVERSITY INDICES AND SEASONAL DISTRIBUTION ASSESSMENT IN ROAD-SIDE MARKETS OF SOUTH-WEST NIGERIA
}

\author{
M. O. Mustafa*, O. A. Lawal, O. O. Fafioye, A. A. Aladesida, F. B. Olowoyo, J. Q. Nwa- \\ Chukwu, A. N. Euzu, C. C. Nwachukwu, C. O. Ezekwe, O. O. Ovuike And R. A. Ugwu. \\ (M. O. M., F. B. O. \& O. O. O: Forestry Research Institute of Nigeria, Federal College of \\ Forest Resources Management, Ishiagu, Ebonyi State, Nigeria; O. A. L. \& O.O.F: Olabisi \\ Onabanjo University, Ago-Iwoye, Ogun State, Nigeria; A. A. A.: Federal University of Agricul- \\ ture, Abeokuta, Ogun State, Nigeria; J. Q. N., A. N. E., C. O. E. \& R. A. U.: Forestry Research \\ Institute of Nigeria, Humid Forest Research Station, Umuahia, Abia State, Nigeria; C. C. N.: \\ Michael Okpara University of Agriculture Umudike, Abia State, Nigeria). \\ *Corresponding author's email: mustafamusiliyu@yahoo.com
}

\begin{abstract}
Wildlife species are under serious exploitation by the rural populace in Nigeria because human beings have understood their ecology. The need to update the existing knowledge of wildlife population is therefore essential. Twenty-three games markets along five Roads in South-west Nigeria were visited to document the wildlife displayed for sale. Two hundred and fifty copies of structured questionnaire were administered using systematic random sampling (odd) method for wildlife species information from market stakeholders. Direct method was counting for species and their numbers. Data generated were analysed through Species Diversity Indices Assessment. All emergent species were compared with International Union for Conservation of Nature (IUCN) abundance rating. Road seasonal distribution of the marketed wildlife was determined by percentages, standard deviation, standard error of mean, mean differences, t-test, and tests of significance and Diversity Indices. Results revealed that 69,398 wild animals were displayed. Also more wildlife were sold during rainy than dry seasons. Appropriate recommendations of government sensitization of rural and urban settlers against over-utilization of wildlife resources, encouragement of the public towards animal domestication and others were made.
\end{abstract}

Keywords: Wildlife diversity, distribution, exploitation, conservation, habitat.

\section{Introduction}

Species Diversity is an expression of taxonomic variety of living organisms which is one among the three principal levels of biodiversity (genetic, species and ecosystem) (Chiarichi et al., 2011). Biological diversity is an expression that refers to the variety of plants, animals, microorganisms and general ecosystem functioning (Kanieski et al., 2011).
Smithsonian Environmental Research Centre (2020) argued that when scientists assess an area's biodiversity, they examine species richness (indicating different species) and the number of organisms presenting each species, they also predict a healthy ecosystem when enough predators, prey, producers and decomposers keep the food web stable. 
Weather, particularly rainfall and temperature influence wildlife resources' habitats, distribution and abundance in their day-today life activities (Kupita et al., 2017). Taylor and Dunstone (2020) also reported that it is difficult to think of any wildlife that is not affected by humans or their actions; in the same vein Nyhus (2016) observed that human interactions with wildlife are both positive and negative as they co-exist: people exploit wildlife for food and other resources, in the process eliminating "dangerous" species, tame some and domesticate some others. The same author wrote that wildlife destroys human investments especially on farms as they forage for food. Roads have negative impacts on biodiversity. To this effect, Parris and Schneider (2010) studied effects of roads on environment and linked road transportation with habitat loss and fragmentation, air, water and soil pollution with constraints in acoustic communication.

Watson (2005) checked impact of road construction on wildlife habitats, he reported that roads divide large landscapes into smaller patches and interior habitats where logging that reduces availability of cover brings together species that might otherwise not interact, leading to predation; intense hunting, disease and parasitism. Each year, hundreds of millions of plants and animals are lost from the wild as food, pets, ornamentals, leather, tourist curios and medicine, while a lot is illegal and survival threatening, many lead to overexploitation and habitat loss (World Wildlife
Fund, 2015). Hunting in Bioko has reduced primate population in Equatorial Guinea by $90 \%$ in some areas; beautiful forests are becoming increasingly silent as their wildlife is hunted (WCS, 2015). Klein (2015) also studied the health status of game animals from which meats are produced; he concluded that some meat samples harbour infectious agents that are not destroyed by smoking, salting nor brining.

\section{Study area}

\section{Experimental}

This study was carried out in roadside wildlife markets in south-west Nigeria from January 2012 and December 2013. The study area were the catchments of five highways within Southwest Nigeria: Ibadan-Ife-Ado Ekiti road named Road 1 (264 km), Ibadan-Ife-Akure road tagged Road $2(204 \mathrm{~km})$, Ibadan-OyoOgbomoso road or Road 3 (120 km), LagosBenin road (from Sagamu Interchange to Ore Junction in Ondo State $(153 \mathrm{~km})$ labelled Road 4 and Lagos - Ibadan (from Sagamu Interchange to old Ibadan Toll Gate) or Road 5 that covers $(62 \mathrm{~km})$ (Fig. 1). Wildlife markets within 100 metres off the road on both sides of the expressways were demarcated /mapped and used for the study. Materials used were field notes, pens and pencils, structured questionnaires and Global Positioning System (GPS) equipment: Trimble Juno SD indicated the markets' geographical locations. The markets are listed in Table 1. 


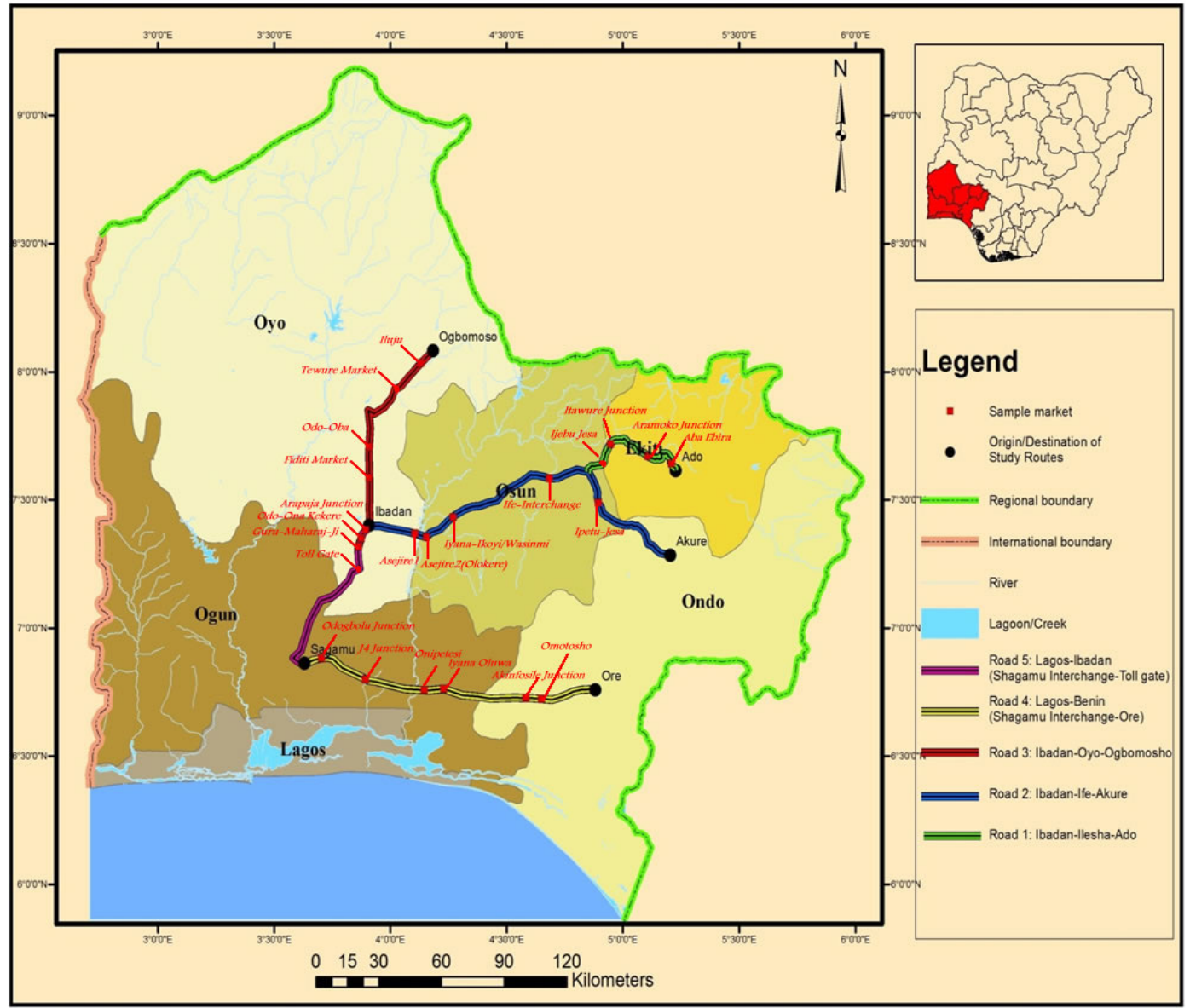

Fig. 1: The study area showing the roads and major neighbouring settlements. 


\section{TABLE 1}

Market locations along the study roads.

\begin{tabular}{|c|c|c|c|c|}
\hline $\begin{array}{l}\text { Market } \\
\text { Roads }\end{array}$ & Locations & $\mathbf{k m}$ & Markets and the Coordinates & $\begin{array}{l}\text { States } \\
\text { Covered }\end{array}$ \\
\hline 1 & $\begin{array}{l}\text { Ibadan-Ife-Ilesa- } \\
\text { Ado-Ekiti Road }\end{array}$ & 264 & $\begin{array}{l}\text { Ijebu Jesa, } 7^{0} 41^{1} \mathrm{~N} 4^{\circ} 49^{1} \mathrm{E},+223 \mathrm{~m} ; \\
\text { Itawure Junction } 7^{\circ} 44^{1} \mathrm{~N}, \\
4^{\circ} 57^{1} \mathrm{E},+265 \mathrm{~m} ; \\
\text { Aramoko Junction } 7^{\circ} 43^{1} \mathrm{~N}, \\
5^{\circ} 3^{1} \mathrm{E},+300 \mathrm{~m} ; \\
\text { Aba Ebira (Ado-Iyin Road) } 5^{\circ} 34^{1} \mathrm{~N}, \\
4^{\circ} 12^{1} \mathrm{E},+313 \mathrm{~m} \\
\text { Total: } 4 \text { Markets }\end{array}$ & $\begin{array}{l}\text { Oyo, Osun } \\
\text { and Ekiti }\end{array}$ \\
\hline 2 & $\begin{array}{l}\text { Ibadan-Ife- } \\
\text { Akure Road. }\end{array}$ & 204 & $\begin{array}{l}\text { Asejire } 1: 7^{\circ} 20^{1} \mathrm{~N}, 5^{\circ} 3^{1} \mathrm{E},+137 \mathrm{~m} \\
\text { Asejire2(Olokere) } 7^{\circ} 22^{1} \mathrm{~N}, 4^{\circ} 7^{1} \mathrm{E},+145 \mathrm{~m} \\
\text { Iyana-Ikoyi/Wasinmi } 7^{\circ} 24^{1} \mathrm{~N}, 4^{\circ} 13^{1} \mathrm{E}, \\
+213 \mathrm{~m} \\
\text { Ife-Interchange: } 7^{0} 30^{1} \mathrm{~N}, 4^{\circ} 28^{1} \mathrm{E}, \\
+275 \mathrm{~m} . \\
\text { Ipetu-Jesa } 7^{\circ} 41^{1} \mathrm{E}, 4^{0} 49^{1} \mathrm{E}+294 \mathrm{~m} \\
\text { Total : } 5 \text { Markets }\end{array}$ & $\begin{array}{l}\text { Oyo, Osun } \\
\text { and Ondo }\end{array}$ \\
\hline 3 & $\begin{array}{l}\text { Ibadan-Oyo- } \\
\text { Ogbomosho } \\
\text { Road }\end{array}$ & 120 & $\begin{array}{l}\text { Fiditi Market, } 7^{\circ} 39^{1} \mathrm{~N}, 14^{\circ} 41^{1} \mathrm{E},+302 \mathrm{~m} \\
\text { Odo-Oba: } 7^{\circ} 27^{1} \mathrm{~N} ; 4^{\circ} 45^{1} \mathrm{E},+306 \mathrm{~m} \\
\text { Tewure Market } 7^{\circ} 25^{1} \mathrm{~N} ; 4^{\circ} 34^{1} \mathrm{E},+277 \mathrm{~m} \\
\text { Iluju: } 7^{\circ} 27^{1} \mathrm{E} ; 4^{\circ} 46^{1} \mathrm{E},+299 \mathrm{~m} \\
\text { Total: } 4 \text { Markets }\end{array}$ & Oyo \\
\hline 4 & $\begin{array}{l}\text { (Sagamu- Ore } \\
\text { road) }\end{array}$ & 153 & $\begin{array}{l}\text { Odogbolu Junction } 6^{\circ} 51^{1} \mathrm{~N} ; 4^{\circ} 33^{1} \mathrm{E} \text {, } \\
+63 \mathrm{~m} \\
\mathrm{~J} 4 \text { Junction } 6^{\circ} 44^{1} \mathrm{~N} ; 4^{\circ} 19^{1} \mathrm{E},+72 \mathrm{~m} \\
\text { Onipetesi } 6^{\circ} 44^{1} \mathrm{~N} ; 4^{\circ} 33^{1} \mathrm{E},+98 \mathrm{~m} \\
\text { IyanaOluwa: } 6^{\circ} 44^{1} \mathrm{~N} ; 4^{\circ} 33^{1} \mathrm{E},+99 \mathrm{~m} \\
\text { Akinfosile Junction: } 6^{0} 52^{1} \mathrm{~N} ; \\
3^{\circ} 59^{1} \mathrm{E},+101 \mathrm{~m} \\
\text { Omotosho: } 6^{\circ} 53^{1} \mathrm{~N} ; 4^{\circ} 7^{1} \mathrm{E} .+259 \mathrm{~m} \\
\text { Total: } 6 \text { Markets }\end{array}$ & Ogun, Ondo \\
\hline 5 & $\begin{array}{l}\text { Lagos-Ibadan- } \\
\text { Sagamu } \\
\text { Interchange }\end{array}$ & 62 & $\begin{array}{l}\text { Toll Gate } 7^{\circ} 20^{1} \mathrm{~N} ; 3^{\circ} 56^{1} \mathrm{E},+233 \mathrm{~m} \\
\text { Guru-Maharaj-Ji: } 7^{\circ} 22^{1} \mathrm{~N} ; 3^{\circ} 56^{1} \mathrm{E},+189 \mathrm{~m} \\
\text { Odo-Ona Kekere: } 7^{\circ} 14^{1} \mathrm{~N} ; 3^{\circ} 52^{1} \mathrm{E},+165 \mathrm{~m} \\
\text { Arapaja Junction: } 7^{\circ} 18^{1} \mathrm{~N}, 3^{\circ} 52^{1} \mathrm{E},+183 \mathrm{~m} \text {. } \\
\text { Total: } 4 \text { Markets }\end{array}$ & Oyo, Ogun \\
\hline
\end{tabular}

Source: Field Survey, (2013). 
Survey was conducted to locate the wildlife markets. This assisted in documenting the communities within the catchments of the five highways. A pre-test of 50 (retrieved) structured questionnaires administration was carried out for one month using systematic random sampling (odd numbers) method in all the 23 markets to collate the list of animals found in the surrounding forests and markets from time immemorial through farmers, traders and hunters around the markets. This stage was a guide to know the wildlife species displayed for sale in the markets and their survey for distribution and diversity.

Visits to all the wildlife markets identified (Table 1) were done monthly for two years (January 2012 to December 2013) excluding the period for reconnaissance survey to assess animal diversity and distribution in the markets

Indirect method was questionnaire administration: three professional associations were interacted with: Hunters association, Farmers' association and Traders' Association. Through their leaders, the sample size was established at $1,400$. Using $25 \%$ enumeration method, 350 copies of structured questionnaire were distributed through the Associations leaders and 250 were retrieved from the respondents comprising wildlife traders, hunters and farmers whose experiences were not less than 15 years leaders. Direct Methods involved direct count (Soewu, 2008). Wildlife seen were counted and grouped into invertebrates, birds, reptiles and mammals. Species Diversity Indices Assessment was done through species numbers and their percentages through Shannon-Weinner Equitability Index (Margurran, 1988) expressed as (H')

$$
\mathrm{H}=-\sum \frac{p i}{\ln p i}
$$

All emergent species (mammals, birds and reptiles) were compared with International Union for Conservation of Nature (IUCN, 2016) abundance rating.

Road seasonal distribution of the marketed wildlife was determined by percentages, standard deviation, standard error of mean, mean differences, t-test, and tests of significance using Statistical Package for Social Scientists (SPSS). This was done using Simpson's Diversity Index (Simpson, 1949) through the formula $\sum\left(\frac{\mathrm{n}}{\mathrm{N}}\right)_{2}$, where, $\mathrm{n}$ is the number of individual species encountered along each road and $\mathrm{N}$ is the total number of species encountered along all Market Roads in the study area. English and scientific names were confirmed with scientific publications that had previously established the names (Ayodele et al., 1999; Odewo et al.; 2008 and Soewu, 2008).

\section{Results and discussion}

Road species diversity indices

Table 2 explains the pattern of species number diversity along each Road: This was therefore arranged as: $\operatorname{Road} 3<\operatorname{Road} 4<\operatorname{Road} 1<\operatorname{Road}$ $2<$ Road 5. However, wildlife-animal groups/ diversity had no significant difference in tests of significance at 0.05 level of probability. 
TABLE 2

Road Species diversity indices of wildlife.

\begin{tabular}{cccc}
\hline Study Roads & Study Roads & Total Species number & $\begin{array}{c}\text { Total Species } \\
\text { number }\end{array}$ \\
\hline 1 & 30 & 46 & 0.4253 \\
2 & 31 & 46 & 0.4542 \\
3 & 25 & 46 & 0.2954 \\
4 & 29 & 46 & 0.3975 \\
5 & 41 & 46 & 0.7944 \\
\hline
\end{tabular}

Key: Road 1: Ibadan-Ife-Ado-Ekiti, Road 2: Ibadan-Ife-Akure; Road 3: Ibadan-OyoOgbomosho, Road 4; Lagos-Ibadan, Road5: Sagamu Interchange-Ore.

Species and Members' Proportions Diversity Indices in the Study Area

Table 3 examines the diversity indices of all the wildlife species encountered compared with their individual members in all the study zones. It was discovered that Species Diversity of all species and their members along all Market Roads had Significant Difference at $5 \%$ level of probability along Roads 3 and 4 only. This significant difference may be attributable to Road 4 passing through Omo forest reserve where rural communities are many in the Forest Reserve and the local people include farmers and hunters. Also, it is a major road to Eastern and Southern parts of the country which different vehicles ply every moment and where passengers engage in wild meat shopping. Road 3 was significantly different too because the wildlife markets along the roads are located in rural areas of Guinea Savanna where local people are Yoruba farmers and hunters. Fulani herdsmen that rear cattle also combine farming with hunting, they form a significant part of the local population in the axis. Among the wildlife species examined, 3 or $8.1 \%$ have been classified as endangered while $25(67.6 \%)$ were ranked as Least Concern, $2(8.1 \%)$ as Vulnerable; $2(5.4 \%)$ as Data Deficient, $3(8.1 \%)$ as Not Evaluated, $1(2.7 \%)$ as Lower Risk and 1 $(2.7 \%)$ as Threatened according to IUCN, (2016) rating. 
TABLE 3

Diversity indices of species and members 'proportions in the study area.

\begin{tabular}{|c|c|c|c|c|c|c|c|}
\hline Scientific Name & Common Name & Road1 & Road 2 & Road 3 & Road 4 & Road5 & $\begin{array}{l}\text { IUCN } \\
\text { Status }\end{array}$ \\
\hline $\begin{array}{l}\text { Archachatina mar- } \\
\text { ginata }\end{array}$ & $\begin{array}{l}\text { A. Giant Land } \\
\text { Snail }\end{array}$ & -5.5541 & -0.9416 & -0.9232 & -0.6809 & -1.1388 & $\mathrm{LC}$ \\
\hline Achatina achatina & $\begin{array}{l}\text { A. Giant Tiger } \\
\text { Land Snail }\end{array}$ & -0.0001 & -0.0027 & -0.5052 & -0.0083 & -0.0629 & $\mathrm{LC}$ \\
\hline Hippotragus equines & Antelope (Roan) & -0.0006 & -0.0002 & -0.0001 & -0.0003 & -0.0022 & Thr. \\
\hline Cephalophus niger & Black duiker & -0.0006 & -0.0003 & 0.0000 & -0.0002 & 0 & $\mathrm{LC}$ \\
\hline Python regius & Royal Python & -0.0001 & -0.0001 & -0.0005 & -0.0005 & -0.0004 & End. \\
\hline Syncerus afer & Buffalo & -0.0004 & 0.0000 & 0.0000 & -0.0003 & -0.0001 & $\mathrm{LC}$ \\
\hline $\begin{array}{l}\text { Dendrohyrax } \\
\text { dorsalis }\end{array}$ & Bush Tree Hyrax & -0.006 & -0.0019 & -0.0002 & -0.0037 & -0.0036 & $\mathrm{LC}$ \\
\hline Tragelaphus scriptus & Bushbuck & -0.0043 & -0.0002 & -0.0001 & -0.0015 & -0.0009 & $\mathrm{LC}$ \\
\hline $\begin{array}{l}\text { Tryonomys swinde- } \\
\text { rianus }\end{array}$ & Cane rat & -0.0068 & -0.001 & -0.0011 & -0.0328 & -0.0253 & $\mathrm{LC}$ \\
\hline Genetta genetta & Genet Civet cat & 0.0000 & -0.00006 & 0.0000 & 0.0000 & -0.00002 & $\mathrm{LC}$ \\
\hline Naja nigricolis & Spittig Cobra & -0.00005 & -0.00002 & 0.0000 & -0.00001 & -0.00002 & $\mathrm{LC}$ \\
\hline Colubus guereza & $\begin{array}{l}\text { Columbus } \\
\text { monkey }\end{array}$ & -0.0002 & -0.00002 & 0.0000 . & -0.00002 & -0.00002 & Vul. \\
\hline Crocodilus niloticus & Crocodile & -0.00002 & -0.00001 & 0.0000 & -0.00005 & -0.0003 & LR \\
\hline $\begin{array}{l}\text { Gastropyxis samar- } \\
\text { agdina }\end{array}$ & Emerald snake & -0.00006 & 0.00000 & 0.0000 & 0.00000 & -0.0002 & $\mathrm{NE}$ \\
\hline Anomalurus beecrofti & Flying squirrel & -0.00001 & 0.00000 & 0.0000 & 0.00000 & -0.0001 & $\mathrm{LC}$ \\
\hline Herpestis sanguineus & Fox & -0.0009 & -0.0086 & 0.0000 & -0.00004 & -0.0003 & $\mathrm{LC}$ \\
\hline $\begin{array}{l}\text { Francolinus bical- } \\
\text { caratus }\end{array}$ & Francolin & -0.0005 & -0.0011 & 0.0000 & 0.00000 & -0.0002 & Thr. \\
\hline $\begin{array}{l}\text { Cricetomys gam- } \\
\text { bianus }\end{array}$ & Giant rat & -0.0014 & -0.0005 & -0.0001 & -0.1418 & -0.0019 & $\mathrm{LC}$ \\
\hline Perodicticus potto & Bowman's Potto & -0.0013 & -0.00001 & 0.0000 & 0.0000 & -0.00007 & $\mathrm{LC}$ \\
\hline $\begin{array}{l}\text { Cephalophus } \\
\text { rufilatus }\end{array}$ & Grey duiker & -0.0024 & -0.0066 & -0.0009 & -0.023 & -0.185 & $\mathrm{LC}$ \\
\hline Numida meleagris & Guinea fowl & -0.0004 & -0.0048 & -0.0002 & -0.0002 & -0.0069 & $\mathrm{LC}$ \\
\hline Lepus capensis & Hare & -0.0006 & -0.0003 & -0.00008 & -0.0006 & -0.0013 & $\mathrm{LC}$ \\
\hline Civetctis civetta & African civet cat & -0.00008 & -0.0001 & -0.00002 & -0.0002 & -0.0004 & $\mathrm{LC}$ \\
\hline Xerus erythropus & Land squirrel & -0.0003 & -0.0013 & 0 & 0 & -0.00003 & $\mathrm{LC}$ \\
\hline Veranus mabitang & Monitor lizard & -0.0001 & -0.0001 & -0.00001 & -0.0014 & -0.0012 & $\mathrm{DD}$ \\
\hline Manis gigantean & Pangolin & -0.0003 & -0.0031 & -0.0003 & -0.005 & -0.0055 & Vul. \\
\hline Hystrix acristata & Porcupine & -0.0018 & -0.003 & -0.0007 & -0.0091 & -0.0071 & $\mathrm{LC}$ \\
\hline Bitis arietans & Puff adder & -0.0003 & -0.0002 & -0.00002 & -0.0006 & -0.0003 & $\mathrm{NE}$ \\
\hline Erythrocebus patas & $\begin{array}{l}\text { Red Patas } \\
\text { monkey }\end{array}$ & -0.00005 & -0.00006 & 0.00000 & -0.00003 & -0.0004 & End. \\
\hline $\begin{array}{l}\text { Gastropyxis samar- } \\
\text { agdina }\end{array}$ & $\begin{array}{l}\text { Smith water } \\
\text { snake }\end{array}$ & -0.00002 & 0.00000 & 0.00000 & 0.00000 & -0.0003 & $\mathrm{NE}$ \\
\hline Chen caerulesuscens & Swan & 0.00000 & -0.00006 & 0.00000 & 0.00000 & -0.00002 & $\mathrm{LC}$ \\
\hline
\end{tabular}




\begin{tabular}{|c|c|c|c|c|c|c|c|}
\hline Kinixys homeana & Tortoise & 0.00000 & -0.00007 & 0.00000 & 0.00000 & 0.00000 & DD \\
\hline Epixerus epii & Tree squirrel & -0.00002 & -0.00006 & 0.00000 & 0.00000 & -0.0003 & LC \\
\hline $\begin{array}{l}\text { Phargochoerus } \\
\text { africanus }\end{array}$ & Warthog & -0.0001 & -0.0001 & -0.00003 & -0.00006 & -0.0004 & LC \\
\hline $\begin{array}{l}\text { Cephalophus leuco- } \\
\text { gaster }\end{array}$ & White Duiker & 0.0000 & 0.0000 & 0.00000 & -0.0013 & 0.0000 & End. \\
\hline Felis libyca & Wild cat & -0.0006 & -0.00005 & 0.00000 & 0.00000 & -0.0003 & $\mathrm{LC}$ \\
\hline \multirow[t]{5}{*}{ Equus guaga } & Zebra & -0.00003 & 0.00000 & 0.00000 & 0.00000 & -0.00002 & $\mathrm{LC}$ \\
\hline & Total & -5.58454 & -0.97822 & -1.43276 & -0.91191 & -1.4468 & \\
\hline & Mean & -0.15093 & -0.02644 & -0.03872 & -0.02465 & -0.0391 & \\
\hline & Chi-sq & 15.919 & 21.459 & 124.568 & 69.432 & 24.865 & \\
\hline & $\operatorname{Sig}(5 \%)$ & $0.774 \mathrm{NS}$ & $0.371 N S$ & oSig. & oSig. & $0.207 \mathrm{NS}$ & \\
\hline
\end{tabular}

KEY:

$\begin{array}{ll}\text { END } & \text { - Endangered } \\ \text { VN } & \text {-Vulnerable } \\ \text { THR } & \text {-Threatened } \\ \text { NE } & \text {-Not Evaluated } \\ \text { DD } & \text {-Data Deficient } \\ \text { LR } & \text {-Lower Risk }\end{array}$

\section{Wildlife seasonal distribution}

Seasonal distribution of the marketed products was assessed for each of the five roads. The most abundant wildlife species was Archachatina marginata (African giant land snail) with $4,386.0$ or $63.2 \%$. Its highest abundance was from Road 3 with dry season figure of 2,895 or $4.2 \%$ and wet season of 8,400 or $12.1 \%$. The species with lowest distribution was Chen caerulescens and were distributed as follows: $2(0 \%)$ from Road 5 Dry Season and $1(0 \%)$ from Road 2 Wet Season. It was absent along the other roads throughout the study (Table 4).

\section{Road seasonal totals from the study}

The road's seasonal totals from the study are shown in Table 5 Wet season distribution was 52636 or $75.8 \%$ while dry season was 1672 or $24.2 \%$. The Road with lowest distribution was Road 4 having a total of 7,473 individuals or $10.7 \%$. The distribution under dry season was
1307.0 or $1.9 \%$ and under wet season it was $6,166.0$ or $8.9 \%$. The highest road dry season figure was from Road 2(6135.0 or 8.8\%) while the lowest Road with lowest number was Road 3 (1307.0 or $1.97 \%)$. The highest wet season Road was Road $3(18,558.0$ or $26.7 \%$ ). The lowest wet season road was road 4 with value of 6166.0 or $8.9 \%$. Rainy season from the study areas has higher number of animals due to the longer period of wet season, huge number of wet season snail catches and the constancy of high numbers of displayed animals year-round along all Roads. Though the seasonal mean difference was not statistically established on individual Road basis, but in the whole study area, it was statistically established. Observation made from this assertion on the basis of seasonal distribution was divided into three schools of thought; The first school believed that animals 
are more abundant during dry season because they are thirsty, heated up, exposed due to dry vegetation, chased by dry season fire, do not breed and search for food so they get caught by hunters (Onyeanusi, 2013). The second school claimed that during rainy season, snails are highly abundant and mammals that are pests of agricultural products have high quality food to feed on, therefore farmers set traps and catch them. Also during early stages of wet season when land cultivation is being done, bush burning happens, so farmers and hunters catch them (Dedeke et al., 2006). The third school of thought supported the two previous think-tanks and criticized them insisting that during dry season moon-light, hunters have low catches; also during wet season especially in August break which is unstable now due to climate change (Odofin et al., 2007) there is dry season weather when heat forces animals out of hiding and makes it easy for both hunters and farmers to trap wild animals abundantly.

Comparison of markets dry and wet seasons' totals and percentages

The parameters considered were the mean, standard deviation, standard error of the mean and their tests of significance. Along all Roads, all the parameters mentioned above had lower values during dry season than during wet season. Even though wet season had more counts than dry season in terms of wildlife displayed for sale, the difference was not significantly different $(\mathrm{P}<0.05)$ along individual roads, but was significant $(\mathrm{P}>0.05)$ in the whole study areas (Table 4)

TABLE 4

Summary of markets dry and wet season totals and percentages.

\begin{tabular}{lccccccc}
\hline $\begin{array}{l}\text { Market } \\
\text { Roads }\end{array}$ & Season (N) & Mean & S.E. & $\begin{array}{c}\text { Mean } \\
\text { Diff. }\end{array}$ & $\begin{array}{c}\text { T } \\
\text { (2-tailed) }\end{array}$ & Df & Sig. \\
\hline \multirow{2}{*}{ Road 1 } & Dry (74) & 32.0 & 15.0 & -62.568 & -917 & 147 & NS \\
& Wet (74) & 94.2 & 66.6 & & & 0.360 \\
Road 2 & Dry (74) & 82.9 & 29.6 & -84.041 & -760 & 147 & NS \\
& Wet (74) & 167.0 & 106.6 & & & 0.173 \\
Road 3 & Dry (74) & 63.2 & 32.1 & -187.61 & -1.37 & 147 & NS \\
& Wet (74) & 250.8 & 133.3 & & & 0.091 \\
Road 4 & Dry (74) & 17.7 & 6.2 & -65.662 & -1.70 & 147 & NS \\
& Wet (74) & 83.3 & 327.6 & & & 0.142 \\
Road 5 & Dry (74) & 30.8 & 9.8 & -85.905 & -1.48 & 147 & NS \\
& Wet (74) & 115.7 & 56.7 & & & \\
Study Area & Dry (370) & 45.3 & 9.5 & -96.956 & -2.41 & 739 & Sig. \\
\hline
\end{tabular}

Source: Field Survey (2013) 
TABLE 5

\begin{tabular}{|c|c|c|c|}
\hline $\begin{array}{l}\text { Market } \\
\text { Roads }\end{array}$ & $\begin{array}{l}\text { Dry Season and } \\
\text { Percentage }\end{array}$ & $\begin{array}{l}\text { Wet Season and } \\
\text { Percentage }\end{array}$ & Totals and Percentages \\
\hline Road 1 & $2,365.0(3.4 \%)$ & $6,995.0(10.1 \%)$ & $9,360.0(13.5 \%)$ \\
\hline Road 2 & $6,135.0(8.8 \%)$ & $12,354.0(17.8 \%)$ & $18,489.0(26.6 \%)$ \\
\hline Road 3 & $4,675.0(6.7 \%)$ & $18,558.0(26.7 \%)$ & $23,233.0(33.4 \%)$ \\
\hline Road 4 & $1,307.0(1.9 \%)$ & $6,166.0(8.9 \%)$ & $7,473.0(10.8 \%)$ \\
\hline Road 5 & $2,280.0(3.3 \%)$ & $8,563.0(12.3 \%)$ & $10,843.0(15.6 \%)$ \\
\hline Total & $16,762.0(24.1 \%)$ & $52,636.0(75.8 \%)$ & $69,398(99.9 \%)$ \\
\hline
\end{tabular}

Source: Field Survey (2013).

Key: Road 1: Ibadan-Ife-Ado-Ekiti, Road 2: Ibadan-Ife-Akure;Road 3: Ibadan-Oyo-Ogbomosho. Road 4; Lagos-Ibadan,Road5: Sagamu Interchange-Ore.

\section{Conclusion and recommendation}

Within the study area, the group of animals that was under the highest exploitation is snails; they are easy to catch because they are sluggish, probably because they have low mental development. Wildlife displayed for sale in the markets were sourced from hunters especially through night hunting and forest snail-picking from the villages and hamlets around and within the neighbouring forest reserves. They were also bought from peasant farmers after trapping animals that are pests of their agricultural products. More animals were harvested during rainy season than dry season, this situation is a pointer that wild animals breed and multiply more in wet than dry season; the fact that more wildlife was harvested in 2013 than 2012 implied that human dependence on wild animals was on the increase. The highest road species diversity of marketed wildlife that came from Road 5, this suggested that demand for wildlife is higher there probably because the road links the two biggest commercial centres (Ibadan and Lagos) in southwest Nigeria. In spite of the fact that wild animals serve as food and Ethno Medicinal materials for both rural and urban settlers, governments at all tiers should encourage the promotion of wildlife utilization and domestication as alternative sources of food, (lean meat for health purposes) through enlightenment strategies and emphasise the consequences of wild animal over-exploitation using various mass media techniques. This will expose rural people and other stakeholders in fauna related jobs to understand the consequences of over-harvesting.

\section{References}

Ayodele, I. A., Ebin, C. O. \& Alarape, A. A. (1999A) Essentials of WildlifeManagement. Power house Publishers Ibadan. 88.

Chiaruchi, A., Bacaro, G. \& Scheiner, S. M. (2011) Old and New Challenges in Using Species Diversity for Assessing Biodiversity All Journals. The Royal Society Publishing Available on-line at https://www.royalsocietypublishing. org.doi..Retrieved 25-05-2020 at 10.25 am.

Dedeke, G. A., Soewu, D. A., Lawal, O. A. \& Ola, M. (2006) Pilot Survey of Ethnozoological Utilisation of Vertebrates in South-western Nigeria, Indilinga. Afr. J. Indigenous Knowl. Syst. 5 (1), 87 - 96.

INTERNATIONAL UNION FOR CONSERVATION OF NATURE (IUCN) (2016) Available atwww.iucnredlist.org.details/4176810 retrieved12 July, 2016. 
Kanieki, M. R., Longhi, J. S. \& Casemiro, P. R. (2017) Methods for Biodiversity Assessment: An Open-access Reviewed Chapter. Available on-line at https://www.interchopen.com. books.Retrieved 25-05-2020 at10.25 am.

Kupita, O. L., Gandiwa, E., Kativu, S. \& Nhamo, G. (2017) Impact of Climate and Climate Variability on Wildlife Resources in Southern Africa. Experience from Selected Protected Areas in Zimbabwe. An Open-access Reviewed Chapter. Available on-line at https://www.interchopen.com.books... Retrieved 25-05-2020 at10.25am.

Magurran, A. E. (1988) Ecological Diversity and its Measurement. Chapman and Hall, London. 431.

Nyнus, P. J. (2016) Human-wildlife Conflict and Co-existence. Annual Review of Environment and Resources, vol. 41 143-171. Available online at https://www.annualreviews.org/doi/full. Retrieved 25-05-2020 at $12.12 \mathrm{pm}$.

Odewo, A. S., Imran, G. T., AdeniJi, K. A. \& OlasuPO, O. O. (2008) Utilization of Wild Animal Parts and its Implication on Wildlife Conservation. Nigeria Journal of Forestry 38 ( 1 \& 2), $23-31$.

Odofin, B. T., Halidu, S. K. \& Akinyemi, O. D. (2007) Implication of Weather and Climate on Sustainable Agriculture in Rainforest Zone of Nigeria. In: Proceedings of International Conference of Nigerian Meteorological Society held at Federal University of Technology, Akure 11 - 15 November, 2007, pp 37-40.

Onyeanusi, A. E. (2013) Director and Head of Wildlife Domestication Section; Head, Department of Forest Conservation and Protection, Forestry Research Institute of Nigeria, Jericho Ibadan. (Personal communication).
PArris, K. M. \& Schneider, A. (2010) Impacts of Traffic noise and Traffic Volume on Birds of Road side Habitats. Ecology and Society 14 (1), 29 (online).www.ecology.comandwww. society.org.vol.14/issl/art29/retrieved 28 October,2017.

Simpson, E. H. (1949) Measurement of Diversity in Nature. Available at www.countrysideinfo.uk/ simpsons.htm. Retrieved 14 August, 2014.

Watson, M. L. (2005) Habitat Fragmentation and Effects of Roads on Wildlife and Habitat. New Mexico Department of Game and Fish. Available on-line at https://wildlife.state.nm.us/ conservation/habitat/handout/documents. Retrieved 21-05-2012.

WILDLIFE CONSERVATION SOCIETY WCS (2015) Wildlife Trade on Wildlife Populations. Available online at www.wcswildlifetrade.org/ aboutwildlifeT. Retrieved 17 April, 2015.

WORLD WILDLIFE FUND (WWF) (2015) Unsustainable and Illegal Wildlife Trade.Available online at . Accessed 17 April, 2015.

SMITHSONIAN ENVIRONMENTAL RESEARCH CENTRE (2020) Understanding Ecosystems for a Sustainable Future. Available on-line at https//www.serc.si.edu/researchtopic. Retrieved25-05-2020 at $10.38 \mathrm{am}$.

Soewu, D. A. (2008). Wild Animals in Ethnozoological Practices among the Yorubas of South-western Nigeria and the Implications for Biodiversity Conservation. African Journal of Agricultural Research 6 (3), 421 - 427. Available on-line at http://www.academicjournals. org/AJAR Retrieved 16 May 2013.

TAylor, V. J. \& Dunstone, N. (2020) The Exploitation, Sustainable Use and Welfare of Wild Animals. Springer Link. Available on-line at https://springer.com. Retrieved 25-05-2020 at $12.01 \mathrm{pm}$.

Received 02 Nov 20; revised 23 Jul 21. 